\title{
Relation between Knowledge Management and Turnover in Slovenian Micro and Small Start-Up Organisations
}

\author{
Riko Novak ${ }^{1}$, Vasja Roblek², Gabrijel Devetak ${ }^{3}$ \\ ${ }^{1,3}$ Faculty of Commercial and Business Sciences Slovenia, Lava 7, 3000 Celje, Slovenia, \\ novak.riko@gmail.com, mandrija@siol.net \\ ${ }^{2}$ University of Primorska, Faculty of Management, Cankarjeva 5, 6104 Koper, Slovenia vasja.roblek@ gmail.com
}

This article discusses the importance of knowledge management and employee turnover, using the example of selected Slovenian organisations, in particular, technology parks. The purpose of this article is to point out statistical characteristics between employee turnover and certain selected independent variables. The empirical research was conducted on a population of 667 Slovenian organisations gathered from the subjects of an innovative environment database, and a further sample of 51 chosen technology parks from the A group. By implementing multivariate regression analysis, we sought to examine whether knowledge requirements and knowledge transfer paths in these organisations have a statistically significant influence on employee turnover. The aim of this article is to present the results of empirical research that defines the development of a conceptual framework for understanding the influence of knowledge management on employee turnover. The results have shown that the importance of intellectual and social capital, intangible capital assets and their continuous measurement must be acknowledged within an organisation.

Key words: employee turnover, knowledge management, organisation, employees

\section{Introduction}

Recently, the business environment has witnessed the development of a relatively large number of industrial clusters and other business networks, which combine knowledge organisations that promote the creation of business information and knowledge exchange (summarised according to Porter, 2000; Brinkley, 2006; Parise, 2007). According to the definitions of some authors (Argyris, 1998; Devinney et al., 2005), knowledge has become the force that gives a competitive advantage to an organisation. At the same time the organisation must employ all mechanisms (e.g. the establishment of a corporative culture) that enable utilisation of internal and external organisational knowledge in everyday business activities. In their research, Prusak and Cohen (2001) stress the crucial role of meaning and evaluation of knowledge management (KM) in organisations. They evaluate KM from the perspective of human resources theory and from the importance of intellectual capital in the emergence, growth and development of an organisational perspective. As a fast growing discipline,
$\mathrm{KM}$ is becoming increasingly important for organisations oriented towards maximising efficiency, innovativeness and, in consequence, competitiveness (summarised according to Rowley, 1999; Davenport and Prusak, 2000). It should also be emphasised that the importance of the development and understanding of KM, has also been on the increase (Drucker, 1994; Leonard-Barton, 1998; Teece, 1998). The reason for this can be found mainly in the recognition of knowledge as the foundation for competitiveness and as a key to business success (Nonaka and Takeuchi, 1995; Pemberton and Stonehouse, 2000; Rebecca et al., 2009).

Based on empirical results, this article gives a basic view of the interlinking, influence on and importance of evaluating $\mathrm{KM}$ for employee turnover in selected organisations that are members of Slovenian technology parks. André (2008) views science-technology parks as centres of scientific-technological development, with a purpose that includes not only research in the laboratory sense but also the transfer of results into practice and the commercialisation of products or services (also known as a modern way of acquiring new technological

Received: $22^{\text {nd }}$ February 2013; revised: $5^{\text {th }}$ April 2013; accepted 10 ${ }^{\text {th }}$ April 2013 
knowledge and consolidating what has been already acquired). Alavi and Leidner (2001) draw attention to the occurrence of science-technology parks of the third generation, which represent an infrastructure for the establishment and development of knowledge-based organisations, which can be found at locations connected with technology centres of excellence (usually universities). From an organisational point of view, a technology park is an isolated "mini city", which started to grow somewhere on the outskirts of a city or on the ruins of older industries. Thus, a technology park can be part of a university, a multinational corporation or individual interested companies.

The final aim of the article is to present empirical findings from data that have been statistically processed in advance and that define the development of a conceptual framework for understanding the influence of KM (as an independent variable) on employee turnover (as a dependent variable). It was recognised that, if an organisation wants to function properly, the importance of intellectual and social capital, intangible capital assets and their continuous measurement must be acknowledged within an organisation.

\section{Theoretical background}

Sustainable development and increased uncertainty in the business environment are forcing dynamic technological organisations to invest in technology and knowledge of employees. For technological micro and small organisations innovation and the intuition of employees can be perceived as the critical success factors (Kuula et al., 2012). An organisation can safeguard its success by providing appropriate business processes, with a tendency towards innovativeness, technological solution search and market needs. One therefore needs to be aware of the importance of knowledge and the creation of a suitable relationship with employees that will work towards the common good. Joint success will be guaranteed if both the organisation and the employees are aware of the importance of knowledge dissemination within the entire organisation and of proper decision-making on the basis of available information.

\subsection{Social capital as a bond between individuals and the organisation}

According to some authors (Adler and Kwon, 2002; Inkpen and Tsang, 2005; Rebelo and Gomes, 2011), social capital is composed of human and intellectual capital, and is based upon the networking of individuals and staff as a whole. This assumption was confirmed by Drucker (2004), who states that management staff must acquire as much information as possible for its work from the external environment. Additionally, Kotler (2004) emphasises that much of the information acquired by mangers originates from outside the organisation, that is to say from business partners, customers and colleagues, as well as state, financial and other institutions. At the same time Cohen and Prusak (2001) emphasise that social capital can be viewed as a state of active connections among people. On this basis, it can be concluded that, compared to a group of individuals, social capital has a greater influence on the growth and success of an organisation. Freeze and Kulkarni (2007) conclude that social capital promotes norms of mutuality, facilitates information flow and, on the basis of former cooperation, enables access to data on the credit status and reputation of stakeholders. Our further research was based on several prior theoretical and empirical starting points on the importance of KM and the phenomenon of employee turnover in an organisation, made by various authors (Zemke et al., 2000; Mathis and Jackson, 2004; Bierly and Daly, 2007; Chatterji, 2009; Phillips and Edwards, 2008).

\subsection{Organisation and knowledge management}

According to the views of some authors (Bollinger and Smith, 2001; Dess et al., 2001; Kujansivu, 2009), today's organisations must be able to react to challenges in the business environment with a clear vision of how to ensure competitiveness, which involves the entire staff at all organisational levels. Alvesson and Karreman (2001) define KM and processes related to knowledge as part of the organisational activities that stem from information systems, organisational sciences, international business and economy. A knowledge organisation thus encompasses a broad spectrum of processes and techniques, with the help of which it generates, connects, selectively divides and effectively uses knowledge through various processes (Carrion-Cepeda, 2006; Reychav and Weisberg, 2006).

According to Becker (2001), knowledge organisations combine their top information technology with highly educated staff that is capable of realising the intended innovation policy of the organisation. On this point, Jarrar (2002) states that this is organisation management with a salient orientation towards knowledge or KM. Additionally, Schein (2010) points out that an organisation obtains new knowledge on the basis of strategic sources. Marshall et al. (1996) understand KM as a process through which we attempt to determine what kind of human capital is embodied in those individuals to which a larger group of individuals - one that is responsible for the development of the organisation - has access to. McElroy (2003) points out that the process of knowledge formation includes individual and group learning, the definition of which knowledge is necessary and information gathering. We can sum up that the purpose of KM is the creation, accumulation and transformation of individual knowledge into organisational knowledge, which is used in business processes (Thierauf and Hoctor, 2006; Fuentes et al., 2007; Armstrong, 2009).

\subsection{Organisation and the importance of employee turnover}

Armstrong (2009) defines turnover in connection with employee satisfaction in the workplace and the sense of belonging to the organisation. In general, it can be understood as the final (permanent) departure of employees from the organisation. It appears when an employee leaves the organisation and has to be replaced. On the basis of the above, it can be defined as a rate for measuring employee departure from the organisation. 
A higher rate value can be disturbing for an organisation and is associated with higher costs arising from the replacement of departing employees with new ones (Schermerhorn et al., 2002). However, when talking about the phenomenon of positive turnover - an unsuccessful and unsuitable employee leaves the organisation - it can be said that such turnover is good and healthy for an organisation (Dalton et al., 1981). The organisation replaces such employees and gains new co-workers with fresh knowledge, new ideas and creativity (Phillips and Edwards, 2008). Franca and Lobnikar (2008) estimate that an employee turnover rate of up to $5 \%$ is necessary in an organisation, a rate of up to $7 \%$ is normal, and a rate of up to $10 \%$ worrying. Tavi and Tollington (2008) are of the opinion that the desired employee turnover rate is lower in organisations that prefer the internal labour market and life-long employment.

\section{Conceptual research framework}

\subsection{Research orientation}

The research concept was based on measuring processes of $\mathrm{KM}$ in Slovenian micro and small start-up organisations that are members of Slovenian technology parks. On the basis of a previously prepared survey questionnaire (Roblek, 2011), we sought data on how organisations acquire knowledge, how much knowledge can be found in organisations, what type of knowledge can be found and how the knowledge is created, transformed, transferred and stored. Thus we analysed the staff potential of organisations, with the aim of establishing how knowledge influences employment and staff development. We concentrated on the evaluation of respondents regarding $\mathrm{KM}$ processes, to find out how $\mathrm{KM}$ influences the efficiency of organisations in Slovenian technology parks in general. The respondents were Slovenian micro and small organisations, and that factor plays an important role in the implementation of KM. Larger organisations have already set up an established organisational structure, whereas in smaller organisations this structure is insufficient. We came to the conclusion that the organisational culture plays a vital role in the implementation of KM processes.

\subsection{Purpose of the article and research question}

The purpose of this article is to describe the influence of KM factors on employee turnover in selected Slovenian technology parks, on the basis of empirical research conducted in 2011. The study was conducted using a survey questionnaire on a population of 667 Slovenian business entities, gathered from the subjects of an innovative environment database maintained by the Public Agency of the Republic of Slovenia for Entrepreneurship and Foreign Investments (JAPTI). On a sample of 51 technology parks from the A group, we sought a connection between the dependent variable (employee turnover in organisations that are members of technology parks) and selected independent variables. Using multivariate regression analysis, we wanted to examine whether KM has a statistically significant influence on employee turnover. The aim of this article is to present results of the empirical research that define the development of a conceptual framework for understanding the influence of knowledge management on employee turnover. In the research three basic hypotheses were set as a starting point and were used to test the basic research question, that is, whether KM has a statistically significant influence on employee turnover: 1 - various KM factors are crucial for the long-term existence and success of an organisation; 2 - connectedness and the influence of knowledge creativity factors, knowledge accumulation and individual knowledge transformation are basic factors for activities and success within an organisation; 3 - the data acquired by the questionnaire is accurate, and on this basis the hypotheses can be verified or rejected. In the following part of the article, the data collection methodology and subsequent statistical processing are described.

\section{Methodology}

\subsection{Data collection}

The empirical data was collected by an online survey questionnaire. The link to the questionnaire was sent to 519 email addresses. The questionnaire was composed of seven blocks of close-ended and open-ended questions relating to the field of knowledge management. The first five blocks were related to KM processes: 1 - environment: development of the organisational culture in connection to $\mathrm{KM}$ and the organisational system in individual organisations; 2 - requirements: knowledge requirements in an organisation; 3 - resources: most valuable resources and knowledge; 4 - knowledge development: knowledge forms within an organisation; 5 - knowledge transfer paths.

The questionnaire on KM processes was composed of approximately 21 questions, for which the respondents were asked to indicate their agreement on an ordinal scale. Closed-ended questions were measured using a four-point Likert Scale to see to which degree respondents agreed or disagreed with the proposed statements $(1-$ strongly agree, 2 - agree, 3 - disagree, 4 - strongly disagree). The sixth block was intended for questions on employee turnover and absenteeism in an organisation. In the seventh block respondents were asked about their demographic characteristics. Before the questionnaire was finally approved, a pilot test was conducted on eight members of the Technology Park in Pomurje. After the testing, the question on knowledge requirements, from the additional question block, as well as the demographic data were supplemented.

\subsection{Population and Research Sample}

The basic empirical research sample comprised 667 organisations which are members or associated members of Slovenian technology parks and university incubators, kept in the JAPTI database under group A. Invitations were not sent to 148 
addresses for the following reasons: 1 - the organisation is a member of a larger technology park; 2 - the organisation does not have an email address; 3 - the organisation has neither a homepage nor an email address. Additionally, we received 51 email responses, in which the respondents explained that they would not participate in our survey for the following reasons: 1 - the content of the questionnaire does not appeal to them; 2 - the organisation has withdrawn from the technology park; 3 - lack of time for answering. On this basis we can assume that other respondents may have ignored the questionnaire for similar reasons. We would like to point out that the survey was conducted among micro and small organisations with fewer employees, who for this reason have to bear a greater burden at work. This is why the response percentage is lower in this segment than it would have been in medium-sized or large organisations. Kuan (2005) also addresses the problem of fewer responses on the part of small organisations. Fiffty-one questionnaires were adequately completed and returned; this means that the final response rate amounted to $9.84 \%$. Sixty-eight questionnaires were inadequately completed and were eliminated (more than $15 \%$ of answers were missing).

\subsection{Statistical Data Processing}

The basic overview of the survey results has been processed and presented on the basis of descriptive statistics (tables, graphs). All hypotheses have been tested at a significant rate, which was smaller than $5 \%(\mathrm{P}=0,05)$. The reliability of the questionnaire was tested with Cronbach's alpha, which represents a reliability or consistency coefficient. Furthermore, we have processed the acquired empirical data with the statistical analysis programme SPSS. Using the "Enter Multivariate Regression Analysis", we have analysed the relation between the dependent variable and selected independent variables. The dependent variable is the employee turnover in organisations that are members of technology parks. On the basis of the given independent variables in the questionnaire, we have selected those that have the greatest influence on the emergence of and increase in the social capital rate. Table 1 presents values of the Cronbach's alpha coefficient for items related to the individual parts of the survey questionnaire.
We can see that the Cronbach's alpha value ranges from 0.496 for items concerning knowledge transfer paths to 0.816 for items concerning knowledge requirements. Based on these data, we can conclude that the reliability of the questionnaire is high. Except for the alpha value concerning knowledge transfer paths, which is below the level of 0.60 , all other alpha values are above the acceptability level and reach values over 0.80: knowledge requirements (0.816). In what follows, we present individual empirical findings of the study, which have been processed with adequate statistical methods.

\section{Correlation between knowledge management and employee turnover}

\subsection{Description of the organisations studied}

In the studied Slovenian technology parks, on average more than two thirds of employees have a pre-Bologna university education. Based on the membership and the organisations' activity structure, we assume that most of the members are performing high technology activities that demand educated staff. The average age of the respondents varies between 26 and 60 years (average age is 34). This relatively young population can be connected to the fact that new organisations are being established in incubators and technology parks, especially by students, young graduates and researchers. In the collected empirical data collected we include relatively holistic data on an organisation's activity structure. It was found, that in one-fifth of all cases, information technology is predominant, followed by research and development as well as services. The purpose of the collected data is twofold: on the one hand, to determine the size of the organisations studied, and on the other hand, to calculate the turnover rate in these organisations. Figure 1 depicts the number of employees and their turnover in these organisations from the time of their establishment to 31. 12. 2010.

Based on data concerning the number of employees, we found that our sample comprised micro-organisations, which employ less than 10 employees, and small organisations with less than 50 employees. One-third of the organisations had no

Table 1: Description of variables

\begin{tabular}{|l|c|c|c|}
\hline Items & Cronbach's alpha & $\begin{array}{c}\text { Cronbach's alpha, based on } \\
\text { standardised items }\end{array}$ & N of items \\
\hline Business environment & 0.609 & 0.624 & 14 \\
\hline Knowledge requirements & 0.816 & 0.819 & 10 \\
\hline Value of resources & 0.681 & 0.67 & 14 \\
\hline Knowledge acquisition & 0.767 & 0.783 & 10 \\
\hline Knowledge transfer paths & 0.496 & 0.512 & 14 \\
\hline
\end{tabular}

Source: Authors'own 


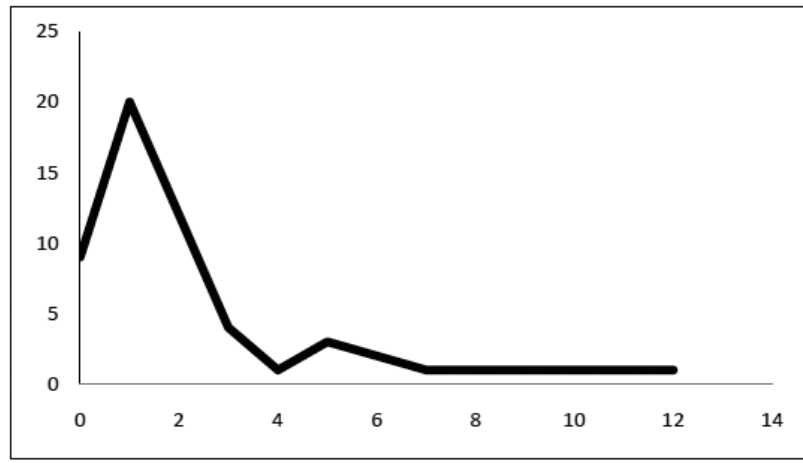

$\mathrm{x}$ - number of employees at the time of establishement $\mathrm{y}$ - number of organisations

Source: authors'own

Figure 1: Number of employees in the organisations studied

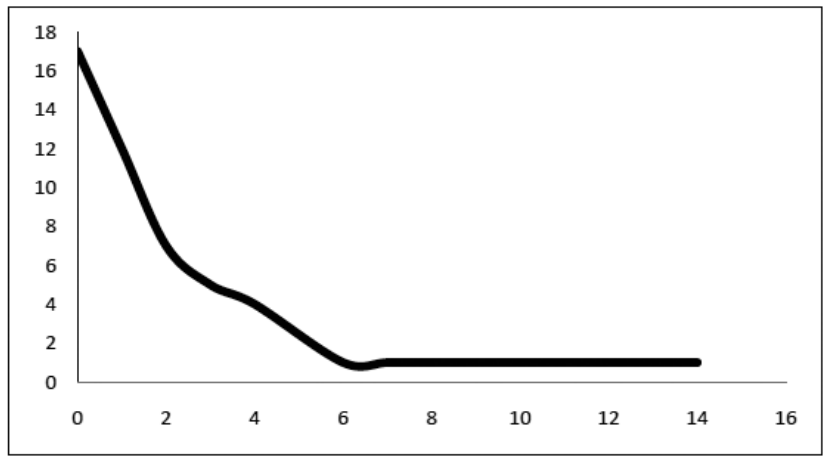

$\mathrm{x}$ - number of new employees at the time of its establishement until 31.12.2010

$\mathrm{y}$ - number of organisations employees at the time of establishment; less than two quarters had one employee; just over one-fifth had two employees, etc. Furthermore, one-third of these organisations hired no employees after the establishment; in just over one-fifth of cases they hired from 1 to 4 employees. During the research period, in most cases no employee had stopped working for the organisation; in other organisations where this was the case, the number was negligible.

\subsection{Importance of KM for the development of small and medium-sized organisations}

For calculating the reliability or consistency of the coefficient, we used the "Cronbach's alpha" method. This is used to determine how well a group of variables or items measures an individual one-dimensional latent structure. A “Cronbach's alpha" value over 0.70 is suitable for determining further internal consistency. Based on the questionnaire results, we have calculated that the "Cronbach's alpha" value varies from 0.496 for items concerning knowledge transfers to 0.816 for questions concerning knowledge requirements. We can conclude that the reliability of the questionnaire is high, since all alpha values are above the acceptability level $(0.70)$. Therefore, we can also conclude that knowledge requirements have a statistically typical influence on KM.

\section{Results}

The hypotheses were tested with the "enter" regression method, which includes all the variables and evaluates the regression coefficients for all independent variables simultaneously (Kazmier, 2004).

Hypothesis testing 1: The demand for knowledge has a statistically significant influence on turnover in technology parks.

In our case the corrected coefficient of the explained variance $\left(\mathrm{R}^{2}\right)$ is $48.4 \%$. The percentage of the explained variance is $51.3 \%$, and this means that the dependent variable is rela-

Table 2: Display regression coefficients - requirements for knowledge

\begin{tabular}{|c|c|c|c|c|c|}
\hline \multirow{2}{*}{ Independent variables } & \multicolumn{2}{|c|}{$\begin{array}{l}\text { Unstandardized } \\
\text { coefficients }\end{array}$} & \multirow{2}{*}{$\begin{array}{c}\begin{array}{c}\text { Standardized } \\
\text { coefficients }\end{array} \\
\text { Beta }\end{array}$} & \multirow{2}{*}{ t statistics } & \multirow{2}{*}{ sig } \\
\hline & B & St. error & & & \\
\hline Technology influence & -0.623 & 0.337 & -0.469 & -1.841 & 0.000 \\
\hline Human influence & -0.625 & 0.41 & -0.521 & -1.522 & 0.000 \\
\hline $\begin{array}{l}\mathrm{R} 2=48.4 \% \\
\mathrm{~F}=84.06 \\
\mathrm{p}<0.01\end{array}$ & & & & & \\
\hline
\end{tabular}


Table 3: Display regression coefficients - requirements for knowledge acquisition

\begin{tabular}{|c|c|c|c|c|c|}
\hline \multirow{2}{*}{ Independent variables } & \multicolumn{2}{|c|}{$\begin{array}{l}\text { Unstandardized } \\
\text { coefficients }\end{array}$} & \multirow{2}{*}{$\begin{array}{c}\begin{array}{c}\text { Standardized } \\
\text { coefficients }\end{array} \\
\text { Beta }\end{array}$} & \multirow{2}{*}{ t statistics } & \multirow{2}{*}{ sig } \\
\hline & B & St. error & & & \\
\hline Communicatiopn technology & 0,107 & 0,386 & 0,312 & 1,251 & 0,003 \\
\hline $\begin{array}{l}\text { Ability of personnel acces to } \\
\text { information resources }\end{array}$ & 0,111 & 0,872 & 0,41 & 1,429 & 0,000 \\
\hline $\begin{array}{l}\mathrm{R} 2=49,56 \% \\
F=76,34 \\
p<0,01\end{array}$ & & & & & \\
\hline
\end{tabular}

Source: Authors'own

tively well explained by the selected independent variables. With the help of F statistics, we tested the whole regression model and in this way measured or validated the meaningfulness of the model as a whole. We got $F=84.06$. Based on this, we can assume that this is a good model that adapts to the data and that it is statistically typical. The influence of the independent variables is also statistically typical. From the standardised regression coefficients, we can conclude that the employees' easy approach to information resources, whether inside or outside the organisation, has the biggest influence on the phenomenon (rate) of turnover. We can therefore conclude that human factor has a statistically significant influence on turnover in small and medium-sized organisations that are members of Slovenian technology parks. An increase of independent variables reduces turnover.

Hypothesis 2: The acquisition of knowledge has a statistically significant impact on social capital in small and mediumsized organisations, members of the Slovenian Technology Parks.

In our case the corrected coefficient of the explained variance $\left(\mathrm{R}^{2}\right)$ concerning the importance and impact of social capital is $49.56 \%$. The share of the explained variance is $49.56 \%$, and this means that the dependent variable is relatively well explained by the selected independent variables. With the help of F statistics, we tested the whole regression model and validated the meaningfulness of the model as a whole $(\mathrm{F}=76.34)$. Based on this, we can assume that this is a good model that adapts to the data and that it is also statistically typical. The impact of both independent variables is statically significant, the standardized regression coefficients and shows that the level of social capital largely affects allow personnel access to information sources, both inside and outside the organisation. Increasing the independent variables increase the level of social capital.

\section{Employee turnover}

Based on the calculation of turnover rate, we classified the respondents in 4 groups: 1 - from 0 to $25 ; 2$ - from 26 to 50 ;
3 - from 51 to $75 ; 4$ - from 76 to 100 percents of turnover. We found that the majority of organisations have a turnover rate between 0 and 25 percent. These relatively high turnover rates can be explained by the fact that these are micro-organisations, which are founded by self-employed persons who can change their status by retaining the status of director of one organisation, while at the same time being long-term employed in another organisation (economics, science, education etc.). The organisations state different reasons behind the occurrence of turnover: 1 - voluntary resignation of employees; 2 - termination because goals were not reached; 3 - retirement; 4 - conflicting interests of employees and the organisation; 5 expiry of employment contract; 6 - lack of financial resources. Moreover, we established that absenteeism is not a disruptive factor in the functioning of micro-organisations that are members of Slovenian technology parks. Only 9.8 percent of respondents drew attention to this problem. The main reason stated was sick leave on account of a child's illness. This can be connected to the fact that these organisations do not have a large number of employees and that they mostly employ relatively young people, without family obligations related to absentism. We can conclude that these organisations different approaches and types of formation, information, planning, transfer and storage of knowledge are being used. We assume that these processes influence knowledge management within the organisations.

\section{Final findings}

The main purpose of this article was to present empirical data on the importance and the influence of KM on employees of organisations that are members of Slovenian technology parks concerning creativity, innovation and job satisfaction. These are resources that Nonaka et al. (2000) define as specific to an organisation and of utmost importance for the creation of value on an individual organisation. In this empirical study we attempted to define the development of a conceptual framework for understanding the influence of $\mathrm{KM}$ on employee turnover in organisations. We had previously studied the theo- 
retical framework and acquainted ourselves with the starting points of various authors who had defined KM processes and the influence of employee turnover. We focused especially on the positive and negative causes of employee turnover that influence the work habits of employees.

We collected empirical data based on a questionnaire completed by 51 micro- and small organisations that are members of Slovenian technology parks. We found that better provision and management of knowledge do lead to better performance and consequently to a greater employee satisfaction. Therefore, we can assume that KM has a typically positive influence on turnover in micro- and small organisations that are members of Slovenian technology parks. Furthermore, we analysed the influence of independent variables ( 1 - influence of technology and human influence (KM); 2 - internal and external influences) on the dependent variable (employee turnover) with the help of the multivariate regression method. We found that there is a statistical correlation between the dependent and independent variables.

Similarly, research on the importance of knowledge management for start-up companies is also carried out in Austria. The results of the Austrian study are mentioned here in order to compare them with the findings of our study. Tangemann et al. (2010) in the study of business-academic incubators in Austria came to the conclusion that the incubated start-up organisations an average age of 2.5 years and create 1.323 jobs. Seventy-two per cent of all jobs created are filled by highly educated staff (university degree), which indicates how intense they are in the field of knowledge creation. An analysis on average annual growth rates showed that two-thirds of all incubated start-up organisations achieved growth, $13 \%$ of organisations have more than doubled the number of employees per year, $29 \%$ of all organisations stagnated and only $5 \%$ reduced the number of employees (Tangemann et al., 2010).

On the basis of the results gathered, we can conclusively report that networking of individuals as well as of organisations with the purpose of increasing processing in the form of knowledge transfer is crucial for both the organisations in general and Slovenian technology parks to function sucessfully. The data and findings are valid only for the sample used for this research. Nonetheless, they can be extended and used on a population with comparable characteristics.

\section{Literature}

Adler, P.S. \& Kwon, S. W. (2002). Social Capital: Prospects for a New Concept, The Academy of Management Review, 27(1): 17 - 40, http://dx.doi.org/10.1234/12345678

Alavi, M. \& Leidner D.E. (2001). Review Knowledge Management and Knowledge Management Systems: Conceptual Foundations and Research Issues, MIS Quaterly, 25(1): 107 - 136, http:// dx.doi.org/10.2307/249403

Alvesson, M. \& Karreman, D. (2001). Odd Couple: Making Sense of the Curious Concept of Knowledge Management, Journal of Management Studies, 38(7): 995 - 1018, http://dx.doi. org/10.1111/1467-6486.00269

André, R. (2008). Organizational behavior: an introduction to your life in organizations. Prentice Hall: Pearson Education International.
Armstrong, M. (2009). Armstrong's Handbook of Human Resource Management Practice, Kogan Page, London, http://dx.doi.org/1 $0.1177 / 0258042$ X0903400407

Bierly, P.E. \& Daly, P.S. (2007). Alternative Knowledge Strategies, Competitive Environment, and Organizational Performance in Small Manufacturing Firms, Entrepreneurship: Theory and Practice, 4(31), 493 - 516, http://dx.doi. org/10.1177/1476127012457979

Becker, M.C. (2001). Managing Dispersed Knowledge: Organizational Problems, Managerial Strategies, and Their Effectiveness, Journal of Management Studies, 38(7): 1037 - 1051, http:// dx.doi.org/10.1111/1467-6486.00271

Bollinger,A. \& Smith, R. (2001). Managing Organizational Knowledge as a Strategic Asset, Journal of Knowledge Management, 5(1): 8 - 18, http://dx.doi.org/10.1108/13673270110384365

Brinkley, I. (2006). Defining the Knowledge Economy: Knowledge Economy Programme Report, The Work Foundation, London, http://dx.doi.org/10.1080/01411920600895676

Carrion-Cepeda, G. (2006). Competitive Advantage of Knowledge Management, Idea Group, London, http://dx.doi. org/10.1108/13673270610679390

Chatterji, A.K., Levine D.I. \& Toffel, M.W. (2009). How Well do Social Ratings Actually Measure Corporate Social Responsibility?, Journal of Economics \& Management Strategy, 18(1): 125 168, http://dx.doi.org/10.1080/0969160X.2012.656411

Cohen, D. \& Prusak, L. (2001). In Good Company: How Social Capital Makes Organizations Work, Harvard Business School Press, Boston, http://dx.doi.org/10.1145/358974.358979

Dalton, D.R., Krackhardt, D. \& Porter, L.W. (1981). Functional Turnover: An Empirical Assessment, Journal of Applied Psychology, 66(6): 716 - 721, http://dx.doi.org/10.1037/00219010.68.3.396

Davenport, T.H. \& Prusak, L. (2000). Working Knowledge: How Organizations Manage What They Know, Harvard Business School Press, Boston, http://dx.doi.org/10.1145/347634.348775

Dess, G.G. \& Shaw, J.D. (2001). Voluntary Turnover, Social Capital and Organizational Performance, The Academy of Management Review, 26(3): 446 - 456, http://dx.doi.org/10.2307/259187

Drucker, P.F. (1994). The Age of Social Transformation, The Atlantic Monthly, 274(5): 53 - 80, http://dx.doi.org/10.1037/0003066X.44.3.546

Drucker, P.F. (2004). What Makes an Effective Executive, Harvard Business Review, 82(4): 58 - 63, http://dx.doi. org/10.1108/14636680810869662

El-Tawy, N.\& Tollington, T. (2008). The Recognition and Measurement of Brand Assets: An Exploration of the Accounting/Marketing Interface, Journal of Marketing Management, 24(7/8): 711 731, http://dx.doi.org/10.1362/026725708X345489

Franca, V. \& Lobnikar, B. (2008). Nagrajevanje delovne uspešnosti: način za zmanjševanje absentizma in fluktuacije, [Rewarding Performance: A Way to Reduce Absenteeism and Turnover], HRM: strokovna revija za ravnanje z ljudmi pri delu [Human Resource Management Magazine], 6(24): 49 - 53.

Freeze, R.D. \& Kulkarni, U. (2007). Knowledge Management Capability: Defining Knowledge Assets, Journal of Knowledge Management, 11(6): 94 - 109, http://dx.doi. org/10.1108/13673270710832190

Fuentes, A.B., Marquez, P.B. \& Albors, J. (2007). A Conceptual and Empirical Approach From Knowledge Management to the Analysus (sic) of the University Industry Relationships, Panorama administrativo, 2 (1): 21 - 50, http://dx.doi.org/10.1 080/10400419.2010.523393

Inkpen, A.C. \& Tsang, E.W.K. (2005). Social Capital, Networks, and Knowledge Transfer, Academy of Management Review, 1(30), 146 - 165, http://dx.doi.org/10.1016/S0268-4012(02)00012-9 
Jarrar, Y.F. (2002). Knowledge Management: Learning for Organisational Experience, Managerial Auditing Journal, 17(6), 322 - 328, http://dx.doi.org/10.1108/02686900210434104

Kazmier, L. J. (2004). Schaum's outline of theory and problems of business statistics. New York: McGraw-Hill.

Kuula, M., Putkiranta, A \& Toivanen, J. (2012). Coping with the change: a longitudinal study into the changing manufacturing practices. International Journal of Operations \& Production Management, 32(2), 106-120, http://dx.doi. org/10.1108/01443571211208597

Kuan, Y. W. (2005). Critical Success Factors for Implementing Knowledge Management in Small and Medium Enterprises, Industrial Management \& Data Systems, 105(3), 261 - 279, http://dx.doi.org/10.1108/02635570510590101

Kujansivu, P. (2009). Is There Something Wrong with Intellectual Capital Management Models, Knowledge Management Research \& Practice, 7(4): 300 - 307, http://dx.doi. org $/ 10.1177 / 0340035206074075$

Leonard-Barton, D. (1998). Wellsprings of Knowledge: Building and Sustaining the Sources of Innovation, Harvard Business School Press, Boston.

Marshall, C., Prusak, L. \& Spilberg, D. (1996). Financial Risk and the Need for Superior Knowledge Management, California Management Review, 38(3): 76 - 101, http://dx.doi. org/10.1108/13673271011050166

Mathis, R.L. \& Jackson, J.H. (2004). Human Resource Management, Thomson/South-Western, Mason.

McElroy, M.W. 2003. The New Knowledge Management: Complexity, Learning and Sustainable Innovation, Butterworth-Heinemann, Boston.

Nonaka, I. \& Takeuchi, H. (1995). The Knowledge-creating Company: How Japanese Companies Create the Dynamics of Innovation, Oxford University Press, Oxford.

Nonaka, I., Toyama, R. \& Konno, N. (2000). SECI, Ba and Leadership: A Unified Model of Dynamic Knowledge Creation, Long Range Planning, 33(1): 5 - 34, http://dx.doi.org/10.1016/ S0024-6301(99)00115-6

Parise, S. (2007). Knowledge Management and Human Resource Development: An Application in Social Network Analysis Methods, Advances in Developing Human Resources, 3(9), 359 - 383, http://dx.doi.org/10.1177/1523422307304106

Pemberton, J.D. \& Stonehouse, G.H. (2000). Organisational Learning and Knowledge Assets - An Essential Partnership, The Learning Organization: An International Journal, 7(4): 184 - 194, http:// dx.doi.org/10.1108/09696470010342351

Phillips, J.J. \& Edwards, L. (2008). Managing Talent Retention: An ROI Approach. John Wiley \& Sons, San Francisco.

Porter, M.E. (2000). Location, Competition and Economic Development: Local Clusters in a Global Economy, Economic Development Quarterly, 14(1): 15 - 34, http://dx.doi. org/10.1177/089124240001400105

Prusack, L. \& Cohen, D. (2001). How to Invest in Social Capital, Harvard Business Review, 6(79): 87 - 93, http://dx.doi.org/10.1 177/107179190200900101

Rebecca, M.G., Joyce, T.H. \& Sheng, W. (2009). The Indirect Relationship Between Organizational-level Knowledge Worker Turnover and Innovation: An Integrated Application of Related Literature, Learning Organization, 2(16), 143 - 167, http:// dx.doi.org/10.1108/09696470910939215

Rebelo, T.M. \& Gomes, A.D. (2011). Conditioning Factors of an Organizational Learning Culture, Journal of Workplace Learning, 23(3), 173 - 194, http://dx.doi.org/10.1108/13665621111117215

Reychav, I. \& Weisberg, J. (2006). Human Capital in Knowledge Creation, Management and Utilization, Idea Group, London, http://dx.doi.org/10.4018/978-1-59140-573-3.ch029
Roblek, V. (2011). [Management znanja in fluktuacija v tehnoloških parkih, Magistrsko delo.] Knowledge Management and Turnover in Technology Parks, Master's Thesis, University of Primorska, Faculty of Management, Koper.

Rowley, J. (1999). What is Knowledge Management?, Library Management, 20(8): 416 - 419.

Schein, E. H. 2010. Organizational Culture and Leadership. San Francisco: Jossey-Bass, http://dx.doi. org/10.1108/01435129910291175

Schermerhorn, J.R., Hunt, J.G. \& Osborn, R.N. (2002). Organizational Behavior, Wiley, New York.

Tangemann, K., Vösnsner, S. \& Laimgruber, S. (2010). Effectiveness of the Austrian business incubator program AplusB (Academia plus Business) - learning for future program design. Quadris Consulting, Graz.

Teece, D.J. (1998). Capturing Value From Knowledge Assets: The New Economy, Markets for Know-how, and Intangible Assets, California Management Review, 40(3): 55 - 79, http://dx.doi. org/10.1177/0018726705057811

Thierauf, R.J. \& Hoctor, J.J. (2006). Optimal Knowledge Management: Wisdom Management Systems Concepts and Applications, Idea Group, London, http://dx.doi.org/10.4018/978-1-59904-016-5

Zemke, R., Raines, C. \& Filipczak, B. (2000). Generations at Work: Managing the Clash of Veterans, Boomers, in Your Work Place, American Management Association, New York.

Riko Novak is a practicing expert in personal business consulting for micro-enterprises, especially in the fields of marketing and the creativity and optimisation of the business process (ideas) in a company. He obtained his professional knowledge in the fields of economic and legal affairs during his graduate and undergraduate studies. He acquired theoretical and practical experience through research in the academic and commercial spheres, which has proven useful in his professional career. In recent years, he has been involved in detailed studies of dynamic entrepreneurship in Slovenia, rapid growth factors of dynamic enterprises and the internationalisation of small and medium-sized (dynamic) enterprises. He is the author and co-author of professional articles, articles presented at national and international conferences, professional publications and research reports.

Vasja Roblek, MSc, is a $\mathrm{PhD}$ student and teaching/ research assistant at the Faculty of Management, University of Primorska, Koper, Slovenia. He completed his Bachelor's studies in banking at the Faculty of Economics, University of Ljubljana and finished Master of Science study at the Faculty of Management, University of Primorska. His main research includes business networking, qualitative methodology, strategic management and social media.

Gabrijel Devetak is an Associated Professor of marketing. For long years he gave lectures at five Slovenian faculties on the theory and praxis of marketing, strategic management, innovation and marketing, as well as on other topics connected to creativity. His lectures for undergraduate and postgraduate students at the University of Primorska, Faculty of Management Koper, at University of Maribor, FOV Kranj, and at the Faculty of Commercial and Business Sciences in Celje are of significant importance. He has 
been a visiting professor at the Faculty of Economics and Business, University of Zagreb and University of Udine. With his 40 years of experiences in the field of economics, he managed to connect business theory and practice, espe- cially with regard to marketing. His bibliography comprises around 1100 works, many of which are university handbooks and specialist books. He has received many social awards for his creative work. 